\title{
The relevance of linguistic and professional knowledge as contributing factors for technical translation in the area of aircraft (maintenance).
}

A relevância dos conhecimentos linguístico e professional como fatores contribuintes para a tradução técnica na área de (manutenção de) aeronaves.

Daniela TERENZI (IFSP) ${ }^{1}$

Maria Claudia Bontempi PIZZI (IFSP) ${ }^{2}$

\section{ABSTRACT}

For security reasons, quantity and constant updates, it is impracticable to translate documents related to the operation and maintenance of aircraft. However, most professionals in this field are not native English speakers and are in contact with this English written documentation on a daily basis so they can do their job. Therefore, it is important that aviation professionals have materials of reference, especially for technical terms, that are reliable sources of information. However, in addition to the lack of this type of material, there is a challenge for its development. The objective of this article is, based on theoretical references and examples from the practice of researching and teaching English for specific purposes, to encourage the discussion about the teamwork of the language teacher and the professional of aircraft maintenance in the production of reference materials, such as technical glossaries. Based on the arguments presented, it is concluded that this partnership has benefits for both areas, languages and technical.

Keywords: Aviation English, Aircraft Maintenance, Documentation, Specific Vocabulary.

\section{RESUMO}

Por questões de segurança, quantidade e constantes atualizações, é inviável a tradução de documentos referentes à operação e manutenção de aeronaves. Porém, a maioria dos profissionais dessa área não são falantes nativos de inglês e estão em contato com essa documentação diariamente para que possam realizar seu trabalho. Portanto, é importante que os profissionais da aviação possuam materiais para consulta, principalmente de termos técnicos, que sejam fontes confiáveis de informações. No entanto, além da escassez desse tipo de material, há o desafio para elaboração dos mesmos. $O$ objetivo deste artigo é, baseado em referências teóricas e em exemplos provenientes da prática de pesquisa e ensino de inglês para propósitos específicos, fomentar a discussão sobre o trabalho conjunto do professor de línguas e do profissional da área da manutenção de aeronaves na elaboração de materiais para consulta, como glossários técnicos. Com base nos argumentos apresentados, conclui-se que essa parceria tem resultados benéficos para ambas as áreas, a de línguas e a técnica.

Palavras-Chave: Inglês para aviação, Manutenção de Aeronaves, Documentação, Vocabulário Específico.

\footnotetext{
${ }^{1}$ Federal Institute of Education, Science and Technology of São Paulo, São Carlos, Brazil. ORCID: https://orcid.org/00000001-9274-3052; daniela.ifspsaocarlos@ifsp.edu.br

${ }^{2}$ Federal Institute of Education, Science and Technology of São Paulo, São Carlos, Brazil. ORCID: https://orcid.org/00000002-1137-4126; mclaudiapizzi@ifsp.edu.br
} 


\section{Introduction}

Documents used in aircraft maintenance, as well as in all fields of aviation, are always written in English and due to their amount, the fact they are constantly being updated and the number of languages they would have to be translated into, their translation is not viable.

Most of maintenance personnel are Airframe and Powerplant mechanics and it is quite difficult to find current numbers about these professionals worldwide. However, Boeing presents an outlook about needs for technician by region taking into account a probable demand between 2019 and 2038 . The perspective is that the aviation industry will require 769,000 new technicians. In Brazil, there were 9,600 of this kind of professionals in 2017, according to the 4th Annual Brazilian Civil Aviation Report (INSTITUTO BRASILEIRO DE AVIAÇÃO, 2019, p. 39). That means thousands of mechanics worldwide must learn how to "understand, read, and write English" (FAA, 2019).

Once the translation of documents used in aviation is not possible and there can be such an impressive number of professionals who will need to understand English to work daily, dictionaries and automatic translators will be a valuable source. Nevertheless, these materials do not always show appropriate translation or explanation considering the specific use of a word in aviation context. Technical dictionaries and glossaries seem to be the best option, especially because they are usually made regarding a specific area.

Working on the elaboration of dictionaries and glossaries for specific purposes is not an easy task owing to the quantity of subareas, such as Airframe and Powerplant in aircraft maintenance. Besides that, it can be difficult for language experts to suggest a proper translation to a word used in a context that is not their expertise area, and subject matter experts may not have all the skills required to build this kind of material. This paper presents information about documentation and aircraft maintenance, contextualizes how it is challenging to find proper translations and meanings in general purposes dictionaries, glossaries and automatic translators providing examples from the practice of researching and teaching English for specific purposes and, at last, presents a reflection considering the benefits of both language and subject matter experts working together.

\section{Aircraft maintenance, its documentation and language challenge}

English is the lingua franca of aviation, used for different types of communication by professionals of this area, such as pilots, air traffic controllers, flight attendants and maintenance staff (SCARAMUCCI; TOSQUI-LUCKS; DAMIAO, 2018) and in aviation history, "accidents have had miscommunication determined either as their main cause, or as a relevant contributing factor to their outcome" (SCHOLLER, 2019, p. 28). Taking that into account, in 2004 the "Manual on the 
Implementation of $\mathrm{ICAO}^{3}$ Language Proficiency Requirements" (known as Doc 9835) was published in order to establish directions for training and testing aviation professionals (TOSQUI-LUCKS; DAMIÃO; SCARAMUCCI, 2018) and its focus is the aeronautical radiotelephony communications, a specialized subcategory of aviation language corresponding to a limited portion of the language uses of controllers and flight crews.

Considering that "the ICAO language proficiency requirements seek to improve communications thereby enhancing safety" (ICAO, 2010, p. 3-2) and, although attention is given to aeronautical radiotelephony communications, aviation language could include all of the language uses of many different professions "within the aviation domain, which itself includes specializations such as aircraft construction, aircraft maintenance, aircraft operations, air traffic control, regulation, airport activities, passenger care, and flight crew" (ICAO, 2010, p. 3-2), the better professionals understand written communication, such as in maintenance environment, the more flight safety is increased.

In order to try to elevate comprehension level of written information, one could suggest that documentation could be translated to technicians' mother language, but that would be quite difficult. ANAC (2017), for example, states that translation is acceptable, as long as it is guaranteed the original information was not changed.

The translation of technical publications (or part of them) into Portuguese, for example, is acceptable as long as it is guaranteed that the translation is appropriate according to the technical terms presented in the original and that no alterations in the procedures or interpretation of these were changed. This can be obtained, for example, through the evaluation of the publication translated by a technical person proficient in the original language of the technical publication ${ }^{4}$ (ANAC, 2017, p. 7-8).

Therefone, it is crucial for translators dealing with technical publications within aviation context to consider that the target audience is formed by professionals, mainly engineers and technicians, who are supposed to perform tasks based on documents, thus message and objectives shall remain the same in order to avoid misunderstandings. Taking into consideration it is mandatory that the information conveys the same meaning, a glossary with specific words will be more valuable than making a version of the document in a language other than English.

Added to the fact that the process required to translate the technical publications would be expensive and time consuming both to its feasibility and evaluation, it would be a huge challenge

\footnotetext{
${ }^{3}$ International Civil Aviation Organization.

4 “[A tradução das PTs [Publicações Técnicas] (ou de parte delas) para o português, por exemplo, é aceitável desde que se garanta que a tradução respeitou os termos técnicos presentes no original e que nenhuma modificação nos procedimentos ou interpretação destes foi alterada. Isto pode ser obtido, por exemplo, por meio da avaliação da publicação traduzida por pessoa técnica proficiente no idioma original da PT]". All translations by the author of this paper, unless otherwise noted.
} 
because of its particularities of technical terms, as discussed ahead; it would also probably be endless considering their large quantity and their need of constant updating.

Aviation Maintenance is guided by and registered in thousands of documents. "The maintenance documentation used in aeronautic domain has three functions: a support of maintenance task, a legal document and a support of training" according to Zafiharimalala and Tricot (2010, p. 3).

There are many different types of documents, such as Aircraft Maintenance Manuals, provided by the aircraft manufacturer to guide how to perform specific tasks of maintenance; Component Maintenance Manuals, issued by the manufacturer of a component that sets out the maintenance actions which can be performed on a given component; Airworthiness Directives, legally enforceable regulations issued by the FAA to correct an unsafe condition in a product; Advisory circulars, refers to a type of publication offered by the FAA to provide guidance for compliance with airworthiness regulations, pilot certification, operational standards, training standards, and other rules; Incident and Accident Reports, featuring the date, time, location, persons and aircraft involved, nature of the event, and all pertinent details of an incident or accident; and finally, forms, with the register of all kinds of information about an aircraft, including its use and maintenance.

Besides the amount of different kinds of documents, the quantity of each type of information in each is also impressive. From December 2019 to February 2020, 51 airworthiness directives were published by $\mathrm{FAA}^{5}$ from a total of 15,564 and a single one can have at least 10 pages. However, an aircraft maintenance manual is much bigger. Technicians, and other professionals, have to deal with almost 100 chapters and about 34,000 pages of an aircraft maintenance manual every day to work with a wide-body plane, without counting its components and their respective manuals.

All technicians are responsible for integrating maintenance instructions from multiple sources, a situation that can make documentation a significant challenge for those who maintain aircraft (FAA, 2012, p. 12), especially because the use of such manuals is mandatory as FAA establishes in the Code of Federal Regulations (FAA, 2019), presented below. Not only FAA requires manuals to be followed during procedures, the Brazilian national civil aviation agency (Agência Nacional da Aviação Civil ANAC) establishes the same requirement, as many others. According to ANAC, the mechanic must be able to understand the continuing airworthiness instructions, including maintenance manuals (ANAC, 2018).

(...) each person performing maintenance, alteration, or preventative maintenance on an aircraft, engine, propeller, or appliance shall use the methods, techniques, and practices prescribed in the current manufacturer's maintenance manual or Instructions for

\footnotetext{
${ }^{5}$ The information was accessed on February $7^{\text {th }}, 2020$ (https://www.faa.gov/regulations_policies/airworthiness_directives/)
} 
Continued Airworthiness prepared by its manufacturer, or other methods, techniques, or practices acceptable to the Administrator (...) (FAA, 2019).

Drury and Ma (2004, p. 118) state "the documentation for repair provided by an English speaking airline is always in English, and this documentation must be used to govern all maintenance tasks, despite a potentially large proportion of mechanics who do not use English as a native language".

According to Sarmento (2004, p. 33), “developed countries, with greater economic power and a more influential culture, in addition to exporting their technologies, will also export their concepts and, consequently, vocabulary referring to specialized languages ${ }^{6}$ " and that is exactly what happens in aeronautics, since the largest companies producing aviation technology are in the United States and England and, as stated by Rabello and Muller (2012, p. 70), "when distributing their aircraft and components around the world, they also distribute their documents, in their languages of origin ${ }^{7 \%}$.

According to FAA, "Aviation maintenance personnel spend from $25-40 \%$ of their time searching for, using and completing maintenance documentation" (FAA, 2005, p. 7). Considering non-native English speakers, Drury and Ma (2003) state that they "can potentially increase their workload, their performance time or their error rate, or even all three measures" due to the fact that all documents are not in their mother language.

The language challenge could be overcome using specialized course books to study and teach Aviation English focusing on written communication. Nonetheless, professionals, students and language teachers do not have many options yet. Most of the materials available, such as English for Aviation: for pilots and Traffic Controllers (ELLIS; GERIGHTY, 2008), Aviation English: for ICAO compliance (EMERY; ROBERTS, 2008), Flightpath: Aviation English for Pilots and ATCOs ${ }^{8}$ (SHAWCROSS, 2011) and English for Cabin Crew (ELLIS; LANSFORD, 2015), were developed, as their titles indicate, for either flight crew members or air traffic controllers and "are not suitable for teaching and learning English for aircraft mechanics, as these professionals must know different aspects of the English language compared to those studied by pilots, controllers or flight attendants ${ }^{9 "}$ (TERENZI, 2019, p. 60).

Other helpful materials are dictionaries and glossaries, but it is also hard to find specific ones for aviation, especially for aircraft maintenance. The Cambridge aerospace dictionary (GUNSTON, 2009) is

\footnotetext{
6 "[Países desenvolvidos, com maior poder econômico e cultura mais influente, além de exportar tecnologias, exportarão também seus conceitos e, consequentemente, vocabulário referente às linguagens especializadas]”.

7 “[(...) ao mesmo tempo em que distribuem suas aeronaves e componentes pelo mundo, distribuem também seus documentos, em suas línguas de origem]".

${ }^{8}$ Air Traffic Controllers.

9 “[(...) não são adequados para o ensino-aprendizagem de inglês para mecânicos de aeronaves, pois esses profissionais devem ter conhecimento de aspectos da língua inglesa diferentes daqueles estudados por pilotos, controladores ou comissários]".
} 
a good reference material and, even though it consists of a huge number of terms, it does not present some specific vocabulary, as will be shown, and it is monolingual, a challenge for those who either have no proficiency in English or no experience in aviation.

\section{Understanding and translating specific vocabulary}

The jargon used in aviation area contains many technical terms mainly in English and the study of terminology becomes a challenge due to the absence of many terms coined in Portuguese along with the fact that many professionals get used to them (RIBEIRO, 2004). Additionally, the number of technical terms is enormous as an aircraft is made up of hundreds of specific components (MULLER; RABELLO, 2013).

There are a few studies that aim at understanding specific vocabulary used in aviation English. Rabello and Muller (2012, p. 68) explain that it is necessary to pay attention to technical texts because "the semantic content of certain linguistic units can be quite different from that considered as usual ${ }^{10 ",}$ using the words "nut" and "spring" as an example.

A simple but interesting example that occurs to us is the use of the English units nut and spring. The common translation for these words in Portuguese language is, respectively, noz [like a walnut] and primavera [the season], however, in the professional metalmechanic sector, the same linguistic signs acquire terminological status, describing technical objects. Thus, the term nut, another translated as noz, is now translated as porca [the nut for a screw], a piece, usually made of steel or cast iron, which is used in conjunction with a screw to provide fixation; the term spring, formerly primavera [the season], in the technical context, is translated as mola, a spiral and elastic element made of very malleable iron that has several uses in various technical areas ${ }^{11}$ (RABELLO; MULLER, 2012, p. 68)

Even though the authors mention "nut" and "spring", these terms are from the professional metal-mechanic sector, also an aviation related area and, as such, are used likewise. According to Rabello and Muller (2012, p. 67), "the translation of specialized texts is an extremely complex activity,

\footnotetext{
10 “[(...) o conteúdo semântico de determinadas unidades linguísticas poder ser bastante diferente daquele tido como o usual]".

11 “[Um exemplo simples, porém interessante, que nos ocorre é o das unidades da língua inglesa nut e spring. A tradução comum para essas palavras na língua portuguesa é, respectivamente, noz e primavera, no entanto, no setor profissional metalmecânico, os mesmos signos linguísticos adquirem status terminológico, descrevendo objetos técnicos. Assim, o termo nut, outra traduzido como noz, passa a ser traduzido como porca, uma peça, geralmente confeccionada em aço ou ferro fundido, que é utilizada em conjunto com um parafuso para propiciar fixação; já o termo spring, outrora primavera, no contexto técnico, é traduzido como mola, um elemento espiral e elástico confeccionado em ferro muito maleável que possui diversas utilidades em variadas áreas técnicas]”.
} 
as an aggravating factor, the more closed the area of activity in which there is a need to translate, the greater the challenges for the translator ${ }^{12}$ ".

Terenzi and Pantoja (2018, p. 21) developed an exploratory study searching for the translation of selected words from a material provided by FAA in translators, glossaries and dictionaries and found out "it is hard to find appropriate translations for some words ${ }^{13}$ ". After searching for the meaning and/or translation to the word "lockbolt" in an automatic translator, in some dictionaries and glossaries, the authors were not able to find information about it. According to them, "the translation to the term lockbolt was not found in any of the research sources. "Lockbolt" is a type of fastener and there is not, based on our research, any translation of the term in Portuguese ${ }^{14 "}$ (TERENZI; PANTOJA, 2018, p. 10).

At times it is not possible to find out the meaning of a word in dictionaries, such as the example given, and sometimes it is not difficult to get a translation for a word and that does not mean the problem is solved. The word "segurança" in Portuguese has two possible translations into English, "safety" and "security" and even when the definitions are taken from a notorious dictionary, the explanation is insufficient for using each of them accurately in aviation context. Because of that, Costa and Camargo (2016), based on a corpus, analyzed how both words are used in this context.

By analyzing the co-text of the term "safety", it was observed that its use occurs in situations related to care, prevention, care, concern for the well-being of those involved, as well as preservation of property. (...) [I]t was observed that the aspects involving the security context of the term "security" involve meanings associated with threat, defense by additional measures, presence of risk, intention to cause damage and defense against acts of unlawful interference, against threats to the integrity of the involved ones, as well as property and the environment as a whole ${ }^{15}$ (COSTA; CAMARGO, 2016, p. 9)

The study about "safety" and "security" is very interesting, pertinent and relevant, especially because the authors were able to explain the words use based on authentic texts. However, it is far from enough. During classes, it is pretty common to hear questions from students who are unsure about the difference between "screw" and "bolt", "smoke" and "fumes" or "airplane" and "airliner". These words are usually confusing for Brazilian learners because of their equal/similar translation, "parafuso", "fumaça" and "avião", respectively.

\footnotetext{
12 "[A tradução de textos de cunho especializado é uma atividade extremamente complexa, como fator agravante, quanto mais fechada for a área de atividade em que exista a necessidade de traduzir, maiores serão os desafios para o tradutor (...)]". 13 " [(...) há dificuldades para encontrar traduções adequadas de alguns termos]".

14 "[A tradução para o termo lockbolt não foi encontrada em nenhuma fonte de pesquisa. Lockbolt é um tipo de prendedor/fixador e não há, com base em nossa pesquisa, uma tradução do termo para o português]".

15 "[Analisando o cotexto do termo "safety", foi observado que seu uso se dá em situações relacionadas a cuidados, prevenção, zelo, preocupação com o bem-estar dos envolvidos, assim como preservação da propriedade. (...) [F]oi observado que os aspectos que envolvem o contexto de segurança do termo "security" envolvem sentidos associados à ameaça, defesa por medidas adicionais, presença de risco, intenção/dolo de causar danos e defesa contra atos de interferência ilícita, contra ameaças à integridade dos envolvidos, assim como à propriedade e ao meio como um todo]".
} 
In Portuguese, "screw" and "bolt" can be translated as "parafuso", but the words in English are different because they indicate two distinct types of fasteners (TERENZI; PANTOJA, 2018). "Smoke" and "fumes" are "fumaça" and "vapores" in Portuguese and the main difference is that smoke is emitted when something is burning and the word fumes is usually used for vapors and they do not necessarily come from fire. In another case, to better understand the use of "airplane" and "airliner" in aviation context, Pinto and Terenzi (2019) conducted a research based on corpus and concluded that appropriate translations might be "avião" for "airplane" and "avião de carreira" for "airliner", considering airline is a company that provides air transport services.

Rabello and Muller (2011) show us another example, similar to "bolt - screw" and "safety security", of different words used for similar things. "Packing" is a component used in the pneumatic sealing systems of the airplane but there are other words related to the same concept: "o'ring", "gasket" and "seal" and even though each word is used for a specific type of sealing mechanism, professionals and students, with no or little experience, might have some questions in practical work situations.

Besides words that are not found in dictionaries, like "lockbolt", and terms that have specific use in aviation context, such as "safety"and "security", there are others whose translations are informal and quite different from what it should be based on English language. Muller and Rabello (2013) found out, after conducting a case study, that employees of a $\mathrm{MRO}^{16}$ usually use the name "caracol" (that means snail in Portuguese) for the Circle Machine because "the similarity of the aeronautical component with that animal" (MULLER; RABELLO, 2013, p. 58). Another example is "franguinho assado", which could be translated as "roasted little chicken" in English.

This refers to a mobile component, actuator of the aircraft's steering system. The term's origin is due to the associative relationship with a whole roasted chicken, similar to those made in rotating skewer available in bakeries and supermarkets. The technical term that names such concept is Carriage Assembly ${ }^{17}$ (MULLER; RABELLO, 2013, p. $58)$.

During classes, students who have some kind of experience with aircraft maintenance commonly tell the English teacher that they use use a different translation to a word from that presented in the dictionary. "C-clamp" is a type of clamp device typically used to hold a wood or metal work piece and its meaning in Portuguese is "Grampo C" but many technicians know it as "sargento" (sergeant). It is similar to another tool named "Punch", a piece of equipment that cuts holes in a material by pushing a

\footnotetext{
${ }^{16}$ Maintenance, Repair and Overhaul. The acronym is usually used for aircraft maintenance companies.

17 " [Este se refere a um componente móvel, atuador do sistema de direcionamento da aeronave. O surgimento do termo devese à relação associativa com um frango assado inteiro, semelhante aos encontrados em churrasqueiras de espetos rotativos disponíveis em padarias e supermercados. O termo técnico que denomina tal conceito é Carriage Assembly]".
} 
piece of metal through it, that means "perfurador, furador" and is usually called "Saca-pino" (something like pull-pin) by technicians.

Muller and Rabello (2013, p. 60) believe "the lack of knowledge of the foreign language is a major factor for the creation, by those involved in communicative interactions, of internal terminological units ${ }^{18 "}$ and, as a result of this way of translating, it is not hard to find unreliable technical glossaries in the web that tries to explain these kind of specific terms. However, "most of the authors of these materials are experts in the technical area and not people related to language studies ${ }^{19}$ "(BOCORNY, 2011, p. 980).

Problems related to translation in the aviation area are not only an English-Portuguese issue. Li et al. (2018) discussed about the translator's subjectivity in aviation English translation to Chinese. The authors present some interesting registers such as same words that sometimes have a different meaning, for instance “Generator: oxygen generator (氧气发生器), AC generator (交流发电机)” (LI et al., 2018, p. 47). Even for those who do not understand Chinese, it is possible to see that different characters are used for "generator". This is because the first one, oxygen generator, is a device that creates something that did not exist before, while the second, AC generator, does not create anything, but converts the electrical current.

Another topic addressed by the same authors is the polysemy of many words in aviation English. Taking “the word clear as an example, in aviation English, it has meanings like “清除”, “许可”, “净空”, “晴空” etc” (LI et al., 2018, p. 50) which means something similar to "remove, get rid of", “consent, permit", "clearance, headroom" and "clear sky", respectively. According to the dictionary presented below, the word "clear" can be used for all these denotations but, as it can be seen in the example given, the translation to Chinese varies accoding to each meaning.

Clear

to remove or get rid of whatever is blocking or filling something, or to stop being blocked or full;

to give official permission for something;

not blocked or filled; open or available;

pure or easy to see through, with no marks or areas that are less transparent (CLEAR..., 2020).

Li and Jiang (2012, apud LI et al., 2018, p. 50) stated that "ambiguity caused by polysemy is the stumbling block for technical translators to accurately understand the original text" and if polysemy

\footnotetext{
18 “[(...) a falta de conhecimento da referida língua estrangeira é fator preponderante para a criação, por parte dos envolvidos nas interações comunicativas, das unidades terminológicas internas]".

19 "[A maior parte dos autores dessas obras são especialistas da área e não pessoas vinculadas aos estudos da linguagem]".
} 
compromises the understanding of the text, it may cause miscommunication as well, leading to fatal accidents in aviation, therefore reinforcing the role and importance of researches that focus on aviation language.

According to Li et al., (2018, p. 50), "the translator should consider the context and if necessary, ask the professionals for help to eliminate the ambiguity and choose the appropriate meaning". Based on this statement and the examples given, the professionals have an important role in the development process of translating specific vocabulary in order to build up specialized glossaries, and, to our view, it is essential that the language expert, such as an English teacher, participate in the process to conduct the research and properly collect and analyse data in order to get to reliable results.

Therefore, the agents of the translation process (not only professional translators, but also language teachers or subject matter experts who aim at elaborating e reliable translation) need some fundamental characteristics to carry out such activity:

\section{Language skills}

- Perfect command of all aspects and stylistic levels of the first language.

- Thorough knowledge of two or more other languages (...).

Thematic skills

- Familiarity with economics, financial affairs, legal matters, technical or scientific fields.

Translation skills

- A capacity to understand texts in the source language and to render them correctly in the target language, using the register and other language conventions that correspond to their intended purpose.

- A capacity to obtain rapidly and efficiently, in both source language and target language, the background knowledge (...) necessary to produce a translation of professional standard, even in less widely known fields. This includes the ability to use research tools and to become familiar with research strategies.

- A capacity to master computer-assisted translation and terminology tools (...) (KELLY, 2005, p. 26-27).

Taking into account the elaboration of a technical translation, translators, language teachers and subject matter experts need very specific knowledge and, for this reason, they use, as a tool, glossaries with words from certain professional areas to assist in translations. However, according to Tagnin (2009, p. 2),

Although there are many glossaries on the market, few have been designed to meet the needs of the translator, whose main task is to produce a natural and fluent text, either in the mother tongue or in the foreign language. For this reason, a simple list of terms and their equivalents is not enough for them. The text producer needs to know how a word is used, that is, how it is associated with other words. 
Thus, there is specific knowledge that translators need to acquire: "criteria for building a reliable corpus, manipulation of data through specific computer programs, criteria for selecting illustrative examples, techniques for finding equivalent words and notions for the construction of appropriate entries".

Therefore, once again, it is a better option if a language professional and an aviation technician, for example, work together considering they both are required to find proper equivalent words for specific terms. Tagnin (2009, p. 4) also ponders that, although we think about the need to search for equivalent terms in translation, considering that this professional has the objective of elaborating a natural text, there is a need for examples to contextualize the word, "as well as information about the linguistic and textual patterns in which this word occurs, that is, the translator needs to know the collocations and possible phraseology of that lexical item". In case there is no correspondent term in the target language, the translators need to think about other possibilities for translation. To help in their choices, translators can use suggestions for adaptations from experts who work in the specific technical field of the text to be translated and, therefore, have professional, historical, social and cultural knowledge about that context.

\section{Linguistic and professional knowledge together}

Currently, teachers tend to act critically, constantly reflecting on their practice, assuming the position of researcher. With this attitude, teachers start to perceive the problems in their context of action, and to seek answers to what bothers them, contributing to the production of knowledge. However, as the examples given could show, it is a hard task for language/English teachers to deal with vocabulary used in a specific area. Bocorny $(2011$, p. 963) states "the lack of descriptive studies on the specialized language of aviation makes it difficult to create and develop English courses for specific purposes for this area of knowledge 20 ".

Sarmento (2008) has contributed to increase the number of studies and also to help teachers of Aviation English specially for aircraft maintenance with the analysis of modal verbs used in manuals, explaining "an appropriate didactic material must present the modal within its real context of use so that students can understand it when they read the manuals ${ }^{21}$ " (SARMENTO, 2010, p. 227). Therefore, the importance of linguistic researches is undeniable to better understand language characteristics to be

\footnotetext{
20 "[A carência de estudos descritivos sobre a linguagem especializada da aviação dificulta a criação e o desenvolvimento de cursos de Inglês para Fins Específicos para essa área de conhecimento]".

21 "[Um material didático adequado deve apresentar o modal dentro do seu contexto real de uso para que os alunos possam compreendê-lo quando lerem os manuais]".
} 
taught in courses for specific purposes. However, when the study focuses on understanding and maybe translating specific vocabulary, the linguistic knowledge and experience might be not enough.

Rabello and Muller (2012, p.74) state that "the ideal technical translator would be that professional who, in addition to having training in translation field, could also have a desirable understanding of the professional field to which he translates ${ }^{22}$, , but that would be a perfect setting, an ideal situation. In most of the scenarios, language teachers do not have wide know-how of the professional area and end up learning specific information during classes.

Taking it all into account, teamwork among language and subject matter experts would be valuable. Terenzi and Cicogna (2020) reported an experience of teaching how to use aircraft maintenance manuals along with English at the same time in an extracurricular course and observed that "the English teacher was able to better understand the use and types of information contained in maintenance manuals, as well as the teacher from the technical area had the opportunity to understand aspects and characteristics of English language common in this type of document ${ }^{23}$ " (TERENZI; CICOGNA, 2020, p. 93).

So, based on the arguments presented, it is possible to say a glossary written by language and subject matter experts working together might result in a more complete material that would help many professionals, such as translators, students, engineers and technicians from aviation maintenance.

Tagnin (2009) explains, as already mentioned, that most glossaries are based on a previous one and just a few were developed to meet the translator needs as they usually present monolexical terms and there is no extra linguistic information that might help to better understand their possible uses.

\section{Conclusion}

Barbosa (2009, p. 33/40) states that "the lexicon is not transparent and univocal, but opaque and polysemic" and that the words carry "cultural references". In this way, "the language is no longer considered as an instrument for communication, but as a depository of the culture it represents". Culture, in this sense, could mean the culture of a professional field or the organisational culture of a company, as well, set by the characteristics and value systems of a particular context.

Thus, we believe that the literal translation, a translation of a text from one language to another word-for-word, rather than giving the sense of the original and, therefore, mistranslating some words and idioms, does not contribute to a more mobile and dynamic epilinguistic and metalinguistic reflection

\footnotetext{
22 “ $[(\ldots)$ o tradutor técnico ideal seria aquele profissional que, além de possuir formação na área de tradução, pudesse também possuir uma desejável compreensão da área de atuação profissional para a qual traduz]”.

23 "[A professora de inglês pôde melhor compreender o uso e os tipos de informações contidas em manuais de manutenção, bem como o professor da área técnica teve a oportunidade de entender aspectos e características da língua inglesa comuns neste tipo de documento]".
} 
of language, since it does not encourage reflection when seeking to reproduce meanings, being almost mechanical work. In literal translation, the dictionary can be considered the most important tool, while in a more interpretative view of translation, the main source would be the translators themselves (that is to say, their knowledge about language and about the context of the text to be translated).

Translation, ergo, is not a bridge (stable, concrete) between languages, but the river itself (movement, instability, constant change): the opposite banks are separated, but they do not stop communicating by the stream, the fluidity of language. Moreover, we can state that a good translation results from a good interpretation, from a good reading. And in order to become a good reader, it seems to be pertinent to anyone, whether they are professional translators and linguistics experts or not, knowing the context in which they are inserted and also the context in which the text was elaborated.

It is important to emphasize that teamwork, between linguistics and aviation professionals, has the potential of being fertile for translating key words and developing glossaries and other kind of materials in which non-native speakers of English can trust when trying to read and understand important documents. Thus, in general, the intention of this article was to highlight the richness of the translation work and the choices made by the translator, as well as focusing on the importance of teamwork, with the participation of both language and subject matter experts, particulary in very specific areas such as aircraft maintenance.

\section{References}

AGÊNCIA NACIONAL DA AVIAÇÃO CIVIL (ANAC). 2017. Instrução Suplementar Nº 145.109001: revisão C. Available at: <https://www.anac.gov.br/assuntos/legislacao/legislacao-1/iac-e-is/is/is145-109-001>. Access: 10 apr. 2020.

. 2018. Instrução Suplementar No.141-002:

Manual do Curso de Mecânico de Manutenção Aeronáutica. Available at:

$<$ https://www.anac.gov.br/assuntos/legislacao/legislacao-1/iac-e-is/is/is-141-002>. Access: 14 apr. 2020.

BARBOSA, L. M. de A. 2009. O conceito de lexicultura e suas implicações para o ensino-aprendizagem de português língua estrangeira. Filologia e Linguística Portuguesa, n.10-11, p. 31-41.

BOCORNY, A. E. P. 2011. Panorama dos estudos sobre a linguagem da aviação . Revista Brasileira de Linguística Aplicada, 11.4: 963-986. Available at:

$<$ http://www.scielo.br/scielo.php?script=sci_arttext\&pid=S1984-63982011000400009>. Access: 24 mar. 2020.

CLEAR. 2020. In: Cambridge Dictionary. Available at: < https://dictionary.cambridge.org/dictionary/english/clear>. Acess: 6 may 2020.

COSTA, C. E. P.; D. C. CAMARGO. 2016. A corpus-based study of simple terms "segurança", "safety" and "security" in aviation language. Aviation in Focus (Porto Alegre), 1.1: 04-12. Available at: $<$ http://revistaseletronicas.pucrs.br/ojs/index.php/aviation/article/view/23738> . Access: 24 mar. 2020. DRURY, C. G.; J. MA. 2003. Do Language Barriers Result in Aviation Maintenance Errors? Human Factors and Ergonomics Society 47th Annual Meeting Proceedings, Denver, Colorado, October 13-17. 
. 2004. Experiments on Language Errors in Aviation Maintenance. Human Factors and Ergonomics Society 47th Annual Meeting Proceedings, New Orleans LA, 48.1:118-122. ELLIS, S.; T. GERIGHTY. 2008. English for Aviation: for pilots and Traffic Controllers. New York: Oxford University Press.

ELLIS, S.; L. LANSFORD. 2015. English Cabin Crew. New York: Oxford University Press. EMERY, H.; A. ROBERTS. 2008. Aviation English: for ICAO compliance. Londres: Macmillan Education.

FEDERAL AVIATION ADMINISTRATION (FAA). 2005. Operator's Manual: Human Factors in Aviation Maintenance. Available at: $<$ http://www.dviaviation.com/files/45180726.pdf $>$. Access: 04 feb. 2020 .

2012. Technical Documentation Challenges in

Aviation Maintenance: A Proceedings Report. Available at: $<\underline{\text { http://aerosoftsys.com/asi/wp- }}$ content/uploads/2013/05/FAA Human Factors Content.pdf >. Access: 07 feb. 2020.

. 2019. Electronic Code of Federal Regulations e-

CFR: §145.155 Inspection personnel requirements. Disponível em: http://www.ecfr.gov/. Acesso em: 30 set. 2019.

GUNSTON, B. 2009. The Cambridge aerospace dictionary. 2.ed. Cambridge: Cambridge University Press, $808 \mathrm{p}$.

INSTITUTO BRASILEIRO DE AVIAÇÃO. 2019. Anuário Brasileiro de Aviação Civil. Available at:

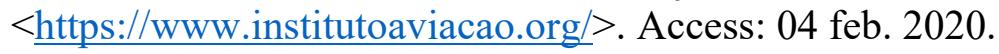

INTERNATIONAL CIVIL AVIATION ORGANIZATION (ICAO). 2010. Manual on the implementation of ICAO language proficiency requirements: Doc 9835 AN/453. 2a ed. Montreal: ICAO.

KELLY, D. 2005. Planning and writing objectives/outcomes. A Handbook for Translator Trainers: a guide to reflective practice. Manchester: St. Jerome, p. 20-41.

LI, H.; X. JIANG. 2012. Translator's subjectivity in science and technology translation. Chinese Science \& Technology Translators Journal, 1.3: 42-44.

LI, Z.; M. ZHU; Y. ZHOU. 2018. The Translator's Subjectivity in Aviation English Translation. International Journal of Applied Linguistics and Translation. 4:3: 46-51. Available at:

$<$ http://www.sciencepublishinggroup.com/journal/paperinfo?journalid=340\&doi=10.11648/j.ijalt.20180 403.11>. Access: 05 may 2020.

MULLER, A. F.; C. RABELLO. 2013. A terminologia presente no interior das empresas: um estudo de caso sobre a variação terminológica em uma empresa de manutenção, reparo e revisão de aeronaves (MRO). ReVEL. 11.21: 50-62. Available at:

$<$ http://www.revel.inf.br/files/20bd0bcc5def4eb0b80f2a9beae449aa.pdf >. Access: 07 feb. 2020.

PINTO, K. S.; D. TERENZI. 2019. Estudo de traduções baseado em corpora multilíngues: análise de termos referentes à aeronave considerando o inglês para aviação. Undergraduation final papel (Tecnologia em manutenção de aeronaves) - Instituto Federal de Educação, Ciência e Tecnologia de São Paulo.

RABELLO, C. E.; A.F. MULLER. 2011. A comunicação especializada em uma empresa de MRO: o papel dos termos. Aviation in Focus (Porto Alegre), 2.1: 13-20. Available at:

$<$ http://revistaseletronicas.pucrs.br/ojs/index.php/aviation/article/view/9282> . Access: 07 feb. 2020. 2012. A tradução de textos aerotécnicos: um estudo de caso em

uma MRO. Aviation in Focus (Porto Alegre), 3.2: 67-75. Available at:

$<$ http://revistaseletronicas.pucrs.br/ojs/index.php/aviation/article/view/13089>. Access: 07 feb. 2020.

RIBEIRO, G. C. B. 2004. Tradução técnica, terminologia e linguística de corpus: a ferramenta Wordsmith Tools. Cadernos de Tradução (Internet). Available at:

$<$ https://periodicos.ufsc.br/index.php/traducao/article/view/6479>. Access: 20 feb. 2020. 
SARMENTO, S. 2004. Embraer 170: Decolagem para o sucesso - Análise do estrangeirismo. Revista da ADPPUCRS. Porto Alegre, 5: 33-40.

. 2008. O uso dos verbos modais em manuais de aviação em inglês: Um estudo baseado em corpus. Tese de doutorado. UFRGS: Porto Alegre.

2010. O verbo modal CAN em manuais de aviação em inglês: implicação para o desenvolvimento de material didático. In: PERNA, C. L.; H.K. DELGADO; M.J. FINATTO. (Ed.). Linguagens Especializadas em Corpora: Modos de Dizer e Interfaces de Pesquisa. 1ed. Porto Alegre: EDIPUCRS, 1: 202-232.

SCARAMUCCI, M.; P. TOSQUI-LUCKS; S. DAMIAO. (Ed.) 2018. Pesquisas sobre inglês aeronáutico no Brasil. Campinas: Pontes, p. 271-293.

SCHOLLER, L. 2019. Aviation radiotelephony: miscommunication in an environment with a multilingual background. In: PACHECO, A. (Ed.). English for Aviation: Guidelines for Teaching and Introductory Research. EDIPUCRS, Porto Alegre.

SHAWCROSS, P. 2011. Flightpath: Aviation English for Pilots and ATCOs. New York: Cambridge University Press.

TAGNIN, S. E. O. 2009. A produção de glossários direcionados pelo corpus e orientados ao tradutor como metodologia de formação de tradutores. In: X Encontro Nacional de Tradutores / IV Encontro Internacional de Tradutores, Ouro Preto, Minas Gerais, Bras. Anais do X Encontro Nacional de Tradutores / IV Encontro Internacional de Tradutores. Ouro Preto, MG, Brasil: Editora da UFOP. Available at: $<$ http://docplayer.com.br/62545180-Anais-do-X-encontro-nacional-de-tradutores-ivencontro-internacional-de-tradutores-abrapt-ufop-ouro-preto-de-7-a-10-de-setembro-de-2009.html>. Access: 09 feb. 2020.

TERENZI, D. 2019. Inglês para propósitos ocupacionais: caminhos e desafios do professor em cursos técnicos e tecnológicos. In: MONZÓN, A. J. B.; FADANELLI, S. B. (Ed.). Ensino de Línguas e Formação Profissional. 1ed. Araraquara: Letraria, 1: 48-72. Available at: $<$ https://www.letraria.net/wpcontent/uploads/2019/10/Ensino-de-L\%C3\%ADnguas-e-Forma \%C3\%A7\%C3\%A3o-ProfissionalLetraria.pdf >. Access: 19 jan. 2020.

TERENZI, D.; T.R. CICOGNA. 2020. Área técnica e de línguas: união de profissionais e experiências em curso de extensão sobre utilização de manuais de manutenção de aeronaves e preenchimento de relatórios de serviços. Revista Compartilhar, São Paulo, 4: 91-93. Available at:

$<$ https://ojs.ifsp.edu.br/index.php/compartilhar/article/view/1040>. Access: 19 apr. 2020.

TERENZI, D.; M.T.B. PANTOJA. 2018. A busca pela tradução de termos técnicos da área de manutenção de aeronaves: um estudo exploratório. Revista CBTecLE, Centro Paula Souza, São Paulo, 1.1: 21-32. Available at: $<$ https://revista.cbtecle.com.br/index.php/CBTecLE/article/view/92>. Access: 19 apr. 2020.

TOSQUI-LUCKS, P.; S.M. DAMIÃO; M.V.R. SCARAMUCCI. 2018. Panorama das Pesquisas sobre Inglês Aeronáutico no Brasil: Contribuições para a Segurança de Voo. Revista Conexão Sipaer, 9.2: 5064. Available at: $<$ http://conexaosipaer.cenipa.gov.br/index.php/sipaer/article/view/505>. Access: 19 apr. 2020.

ZAFIHARIMALALA, H.; A. TRICOT. 2010. Text signals in the aircraft maintenance documentation. Multidisciplinary Approaches to Discourse, Moissac. Available at: $<$ http://andre.tricot.pagesperso-orange.fr/ZafiharimalalaTricot_MAD2010.pdf $>$. Access: 10 mar. 2020.

Daniela Terenzi holds a PhD degree in Linguistics from the Federal University of São Carlos (UFSCar). She is currently Professor at Federal Institute of Education, Science and Technology of São Paulo (IFSP), with experience in Education, mainly in Teaching Methods and Techniques, working with English for Aircraft Maintenance, English and Portuguese Teaching, Development of Teaching 
Materials and English for Specific Purposes. She is the leader of the Research Group on English for Aircraft Maintenance (GPIMA).

Maria Claudia Bontempi Pizzi has a doctoral degree in Linguistics from the Federal University of São Carlos (UFSCar). She works in the areas of Languages and Applied Linguistics, mainly with Language Teaching and Learning, English for Aircraft Maintenance, Translation and Literary Studies, teaching English as a Second Language, English for Specific Purposes and Portuguese at the Federal Institute of Education, Science and Technology of São Paulo (IFSP). In addition, she is a member of the Research Group on English for Aircraft Maintenance (GPIMA). 